\title{
The Effect of Maternal Hyperglycemia on Acid Base Balance and Lung Liquid Production in the Fetal Sheep
}

\author{
FRANCINE G. SMITH AND EUGENIE R. LUMBERS \\ School of Physiology and Pharmacology, University of New South Wales, Sydney: New South Walex, dustralia
}

\begin{abstract}
In 10 chronically catheterized fetal sheep, the effects of $100 \mathrm{~g}$ of glucose infused (intravenous) to the pregnant ewe on lung liquid production and acid-base status were investigated. Maternal and fetal hyperglycemia occurred within $15 \mathrm{~min}$ of the infusion of glucose. There was a significant increase in fetal $\mathrm{PCO}_{2}$ from $41.67 \pm 1.00$ to $46.89 \pm 1.83 \mathrm{~mm} \mathrm{Hg}$ and a decrease in fetal arterial $\mathrm{pH}$ from $7.42 \pm 0.016$ to $7.33 \pm 0.026(n=7)$. This acidosis was probably the result of fetal lactacidemia. There was also a decrease in fetal $\mathrm{PO}_{2}(p<0.001)$ following the infusion of glucose to the ewe. This, along with the acidosis, might account for the increased risk of unexplained fetal death in the diabetic pregnancy especially near term. Following the infusion of glucose to the ewe there was an increase in maternal plasma osmolality by $16 \pm 3.35$ mosmol/ $\mathrm{kg}(n=9)$ and in fetal plasma osmolality by $14 \pm$ $2.64 \mathrm{mosmol} / \mathrm{kg}(n=9 ; p<0.001)$. Fetal lung liquid production fell from $0.195 \pm 0.04$ to $0.093 \pm 0.02 \mathrm{ml} / \mathrm{min}$ $(n=6 ; p<0.001)$. There was no change in the excretion of osmol by the lungs. The decreased lung liquid production was probably due to a decrease in the net movement of fluid across the pulmonary epithelium. (Pediatr Res 22: 355-359, 1987)
\end{abstract}

\section{Abbreviations}

ADH, antidiuretic hormone

iv, intravenous

The perinatal mortality rate for infants of diabetic mothers has been found to be $6.2 \%$ (1), an incidence which is greater than in the nondiabetic population. There is also an increased incidence of unexplained fetal death especially in the last $4 \mathrm{wk}$ of gestation (2) the etiology of which remains unknown. The fetus of a diabetic woman can be exposed to wide fluctuations in blood glucose levels. Thus, one reason for this unexplained fetal death might be maternal nocturnal hypoglycemia observed by Gillmer et al. (3). Another explanation could be exposure of the fetus to hyperglycemia. In the ovine pregnancy, maternal hyperglycemia caused a rise in fetal plasma glucose levels and increased fetal plasma lactate (4). Direct infusion of glucose to the fetus also produced lactacidemia sufficient to cause a significant fall in fetal arterial $\mathrm{pH}$. This effect was more pronounced when fetal $\mathrm{PO}_{2}$ was low (4).

Received November 14, 1986; accepted April 27, 1987

Correspondence and reprint tequests to Francine G. Smith, School of Physiology and Pharmacology. University of New South Wales, P.O. Box 1. Kensington, $2(033$. N.S.W., Australia.

Supported by the Australian Kidney foundation and the National Health and Medical Research Council of Australia. F.G.S. was supported by the Wenkart Foundation of Australia.
Experiments were performed in chronically catheterized fetal sheep to examine the effects of fetal hyperglycemia resulting directly from maternal hyperglycemia on fetal arterial oxygen tension and acid base balance and also to see if there was any effect of hyperglycemia on lung liquid production.

\section{METHODS}

Experiments were carried out in 10 chronically catheterized fetal sheep aged 120 to 138 days.

Surgical details. Anaesthesia was induced with $1 \mathrm{~g}$ sodium thiopentone (Pentothal. Abbott) and maintained with $3 \%$ halothane in oxygen.

Under aseptic conditions, polyvinyl catheters ( $0.5 \mathrm{~mm}$ ID: 1.5 $\mathrm{mm} O D)$ were inserted into a femoral artery and a tarsal vein of the fetus as previously described (5). Through a second uterine incision, the fetal head was exposed, the esophagus ligated and a cannula inserted into the trachea. This cannula was connected to an intrauterine latex rubber bag by a T-piece and joined to a length of polyvinyl tubing ( $1.5 \mathrm{~mm}$ ID: $2.7 \mathrm{~mm}$ OD) so that fetal lung liquid drained continuously into the bag. Each day the intrauterine latex bag was emptied.

Polyvinvl catheters (1.5 mm ID: $2.7 \mathrm{~mm}$ OD) were also inserted into a carotid artery and jugular vein of the ewe. The animals were allowed to recover from anaesthesia and were housed in metabolic cages with free access to lucerne chaff, oats, and water except during the experimental period. Antibiotics (benzyl penicillin $600 \mathrm{mg}$. streptomycin sulphate $1 \mathrm{~g}$. Glaxo) were administered both intramuscularly to the ewe and into the amniotic cavity for 3 days postoperatively. At least 5 days were allowed for recovery from surgery, during which time all fetal lung liquid that had collected in the intrammiotic bag was drained daily.

Experimental protocol. For $45 \mathrm{~min}$ prior to the beginning of an experiment, the lung liquid cannula was allowed to drain freely. Fetal lung liquid was collected at 30-min intervals for 5.5 h. Blood samples $(4 \mathrm{ml})$ were taken from the fetal and maternal arterial catheters at the midpoint of the $3 \mathrm{rd}, 5 \mathrm{th}, 7 \mathrm{th}$ and $10 \mathrm{th}$ collection periods. Whole blood was spun at $4^{\circ} \mathrm{C}$ and plasma removed and stored at $-20^{\circ} \mathrm{C}$. Fetal and maternal blood gases were measured using a $\mathrm{pH} /$ blood gas analyzer (Instrumentation Laboratory-Micro 13). After the first $1.5 \mathrm{~h}, 100 \mathrm{~g}$ glucose in 500 $\mathrm{ml}$ isotonic saline (Travenol) were infused into the ewe (iv) over a $30-\mathrm{min}$ period. The volume of lung liquid collected was recorded and samples stored at $-20^{\circ} \mathrm{C}$. Fetal intraamniotic pressure, fetal and maternal blood pressures were measured using pressure transducers (Statham) and recorded onto a Grass polygraph. Intraamniotic pressure was subtracted from fetal blood pressure. At the conclusion of the experiment the ewe was killed by an overdose of anaesthetic, the fetus was removed. weighed. and the position and patency of the catheters checked.

Chemical analyes. Sodium and potassium levels in lung liquid and plasma were measured using an FLM3 flame photometer 
(Radiometer) and osmolality was measured with an Advanced Digimatic Osmometer (model 3D 11). The glucose present in the plasma and lung liquid was measured with an Autoanalyzer (Technicon) using a glucose oxidase method first described by Keston (6). Plasma bicarbonate was calculated from the formula:

$$
\left[\mathrm{HCO}_{3^{-}}=\right]=0.0294 \mathrm{PCO}_{2} \times 10^{\left(-4.9911+0.6576 \mathrm{pH}+0.0262 \mathrm{pH}^{2}\right)}
$$

derived by Armentrout et al. (7) from the Henderson-Hasselbach equation.

Analyses of data. Data are expressed as mean \pm SEM. Statistics were performed using two-way analysis of variance (Biosoft 1 for the Apple 1 le) and where the F value was found to be significant $(p<0.05)$ a Newman Keuls test was performed to reveal where change(s) occurred.

\section{RESULTS}

The infusion of $100 \mathrm{~g}$ glucose (iv) to the ewe caused an immediate increase in maternal and fetal plasma glucose levels (Fig. 1). Within $15 \mathrm{~min}$, maternal plasma glucose levels had risen from $65.85 \pm 2.8$ to $763.8 \pm 26.8 \mathrm{mg} / \mathrm{dl}(n=10 ; p<0.001)$ and fetal plasma glucose levels from $15.75 \pm 2.8$ to $195.4 \pm 18 \mathrm{mg} /$ dl $(n=10 ; p<0.001)$. Plasma glucose levels were still elevated $3 \mathrm{~h}$ later (Fig. 1). Maternal plasma osmolality increased by $16 \pm$ $3.35 \mathrm{mosmol} / \mathrm{kg}(n=9 ; p<0.001)$ and fetal plasma osmolality by $14 \pm 2.64 \mathrm{mosmol} / \mathrm{kg}(n=9 ; p<0.001$; Fig. 1). Maternal plasma osmolality returned to control levels over the next $3 \mathrm{~h}$ but fetal plasma osmolality remained high $(p<0.001)$. Therefore, the fetal to maternal plasma osmolality ratio increased from a control level of $0.967 \pm 0.007$ to $0.995 \pm 0.0063 \mathrm{~h}$ later $(n=$ $9 ; p<0.05)$.

Within 15 min of the glucose infusion, maternal plasma sodium and potassium levels had fallen $(p<0.001$; Table 1$)$. They returned to control levels by $3.5 \mathrm{~h}$. Fetal plasma sodium decreased over $3 \mathrm{~h}$ following the glucose infusion $(p<0.001)$. There was no change in fetal plasma potassium (see Table 1).
Fetal arterial pressure (corrected for amniotic pressure) was $57.9 \pm 3.2 / 36.9 \pm 3.31 \mathrm{~mm} \mathrm{Hg}(n=8)$ before glucose; there was no change in arterial pressure during the experiment.

There was a rise in maternal $(p<0.05)$ and fetal arterial $\mathrm{PCO}_{2}$ $(p<0.01)$ with hyperglycemia which was sustained for the 3.5 $\mathrm{h}$ following the infusion of glucose (Fig. 2). Fetal arterial $\mathrm{pH}$ and bicarbonate levels decreased in the $3 \mathrm{~h}$ following the infusion of glucose (see Fig. 2). There was also a significant fall in fetal arterial $\mathrm{PO}_{2}(p<0.001$; Fig. 3).

Lung liquid production was $0.195 \pm 0.04 \mathrm{ml} / \mathrm{min}(n=6)$. After the infusion of glucose there was a progressive fall in lung liquid production $(p<0.001)$ to $0.093 \pm 0.02 \mathrm{ml} / \mathrm{min}(n=6)$

Table 1. Maternal and fetal plasma sodium and potassium levels*

\begin{tabular}{|c|c|c|c|c|}
\hline \multirow{2}{*}{$\begin{array}{l}\text { Plasma } \\
\text { sample }\end{array}$} & \multicolumn{2}{|c|}{$\begin{array}{c}\text { Plasma sodium } \\
(\mathrm{mmol} / \mathrm{liter})(n=10)\end{array}$} & \multicolumn{2}{|c|}{$\begin{array}{l}\text { Plasma potassium } \\
(\mathrm{mmol} / \mathrm{liter})(n=9)\end{array}$} \\
\hline & Maternal & Fetal & Maternal & Fetal \\
\hline 1 & $\begin{array}{l}140.4 \\
(0.99)\end{array}$ & $\begin{array}{l}142.4 \\
(1.57)\end{array}$ & $\begin{array}{l}4.22 \\
(0.08)\end{array}$ & $\begin{array}{l}3.8 \\
(0.21)\end{array}$ \\
\hline 2 & $\begin{array}{l}130.3 \\
(2.16)\end{array}$ & $\begin{array}{c}143.1 \\
(1.37)\end{array}$ & $\begin{array}{l}3.14 \\
(0.07)\end{array}$ & $\begin{array}{l}3.7 \\
(0.23)\end{array}$ \\
\hline 3 & $\begin{array}{r}136.2 \\
(3.4)\end{array}$ & $\begin{array}{l}140.1 \\
(0.97)\end{array}$ & $\begin{array}{l}3.4 \\
(0.11)\end{array}$ & $\begin{array}{l}3.93 \\
(0.26)\end{array}$ \\
\hline 4 & $\begin{array}{r}140.2 \\
(1.04)\end{array}$ & $\begin{array}{l}136.3 \\
(1.64)\end{array}$ & $\begin{array}{l}4.02 \\
(0.07)\end{array}$ & $\begin{array}{l}4.1 \\
(0.36)\end{array}$ \\
\hline
\end{tabular}

* Mean (SEM) plasma levels of sodium and potassium before (sample 1) and after (samples 2, 3, and 4) the infusion of $100 \mathrm{~g}$ of glucose to the ewe. Samples 2, 3, and 4 were collected 15,75, and $165 \mathrm{~min}$ after the infusion was finished. Maternal plasma sodium and potassium levels fell $(p<0.001)$ within $15 \mathrm{~min}$ of completing the infusion and returned to control levels by the end of the experiment. Fetal plasma sodium levels were significantly decreased $165 \mathrm{~min}$ after the infusion $(p<0.001)$. There was no change in fetal plasma potassium levels.

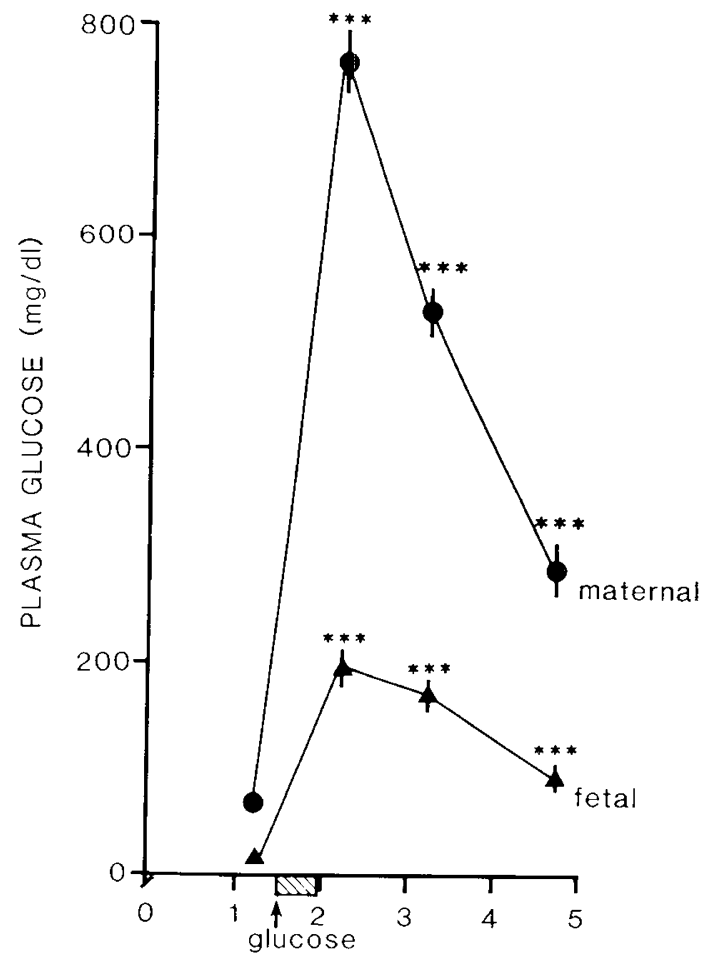

TIME (h)

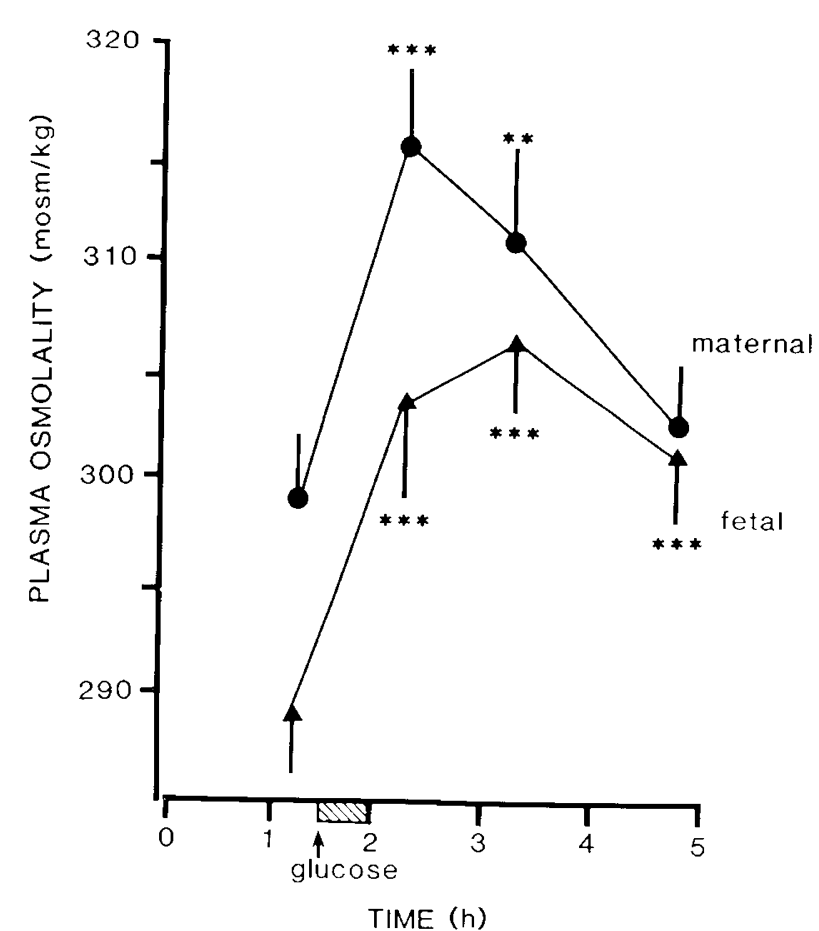

Fig. 1. Mean \pm SEM maternal (closed circles) and fetal (closed triangles) plasma glucose levels ( $\mathrm{mg} / \mathrm{dl}$, left) and plasma osmolality (mosmol $/ \mathrm{kg}$, right) prior to and following the infusion of $100 \mathrm{~g}$ glucose to the ewe. There was a significant increase in both maternal and fetal levels compared with control levels as indicated by asterisks $\left({ }^{* * *} p<0.001 ;{ }^{* *} p<0.005\right)$. 

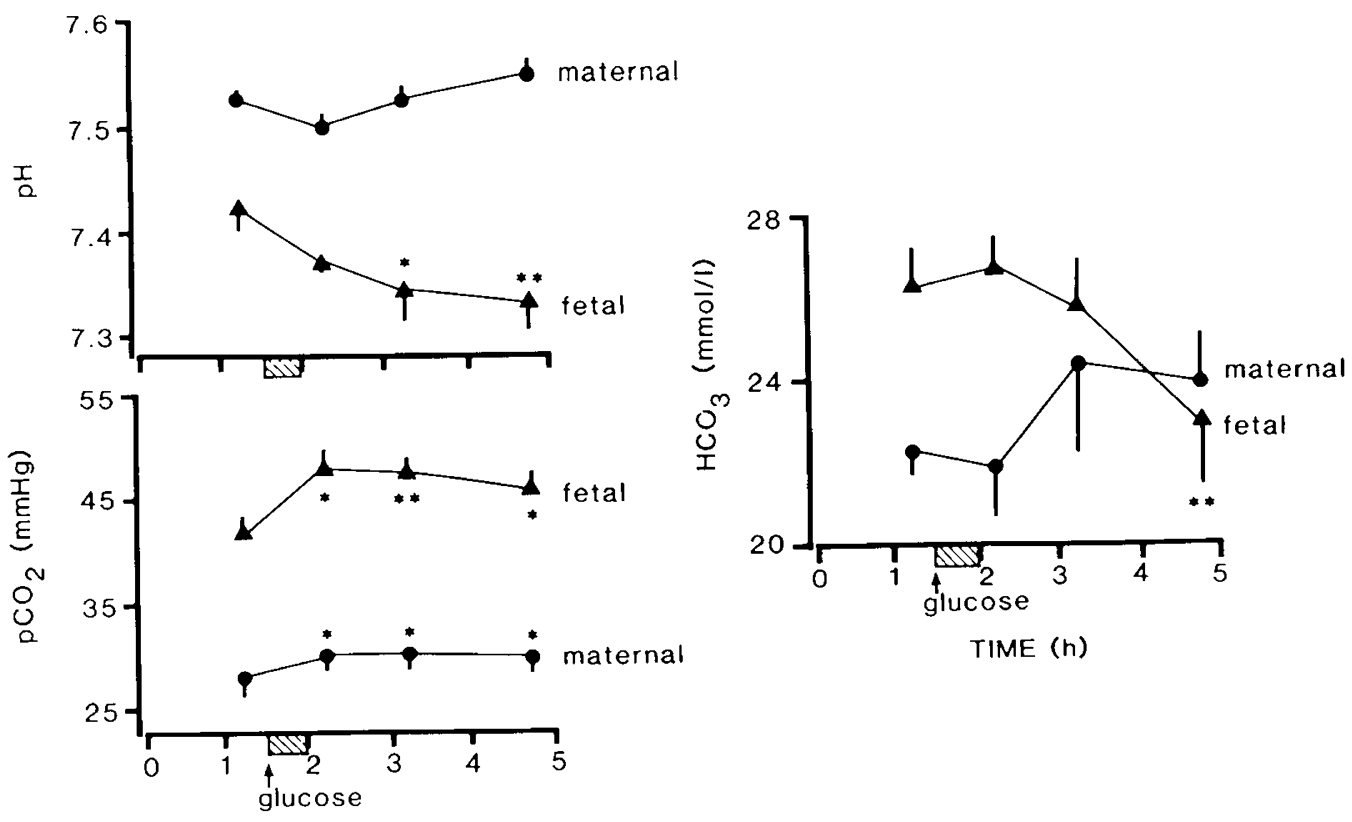

TIME (h)

TIME (h)

Fig. 2. Mean \pm SEM maternal (closed circles) and fetal (closed triangles) arterial $\mathrm{pH}(t o p$ left $), \mathrm{PCO}_{2}(\mathrm{~mm} \mathrm{Hg})$ (bottom left), and bicarbonate levels $\left(\mathrm{HCO}_{3} ; \mathrm{mmol} /\right.$ liter prior to and following the infusion of 100 g glucose to the ewe. Fetal $\mathrm{PCO}_{2}$ increased $\left({ }^{* *} p<0.005,{ }^{*} p<0.01\right)$ while $\mathrm{pH}$ and $\mathrm{HCO}_{3}$ levels fell with fetal hyperglycemia.

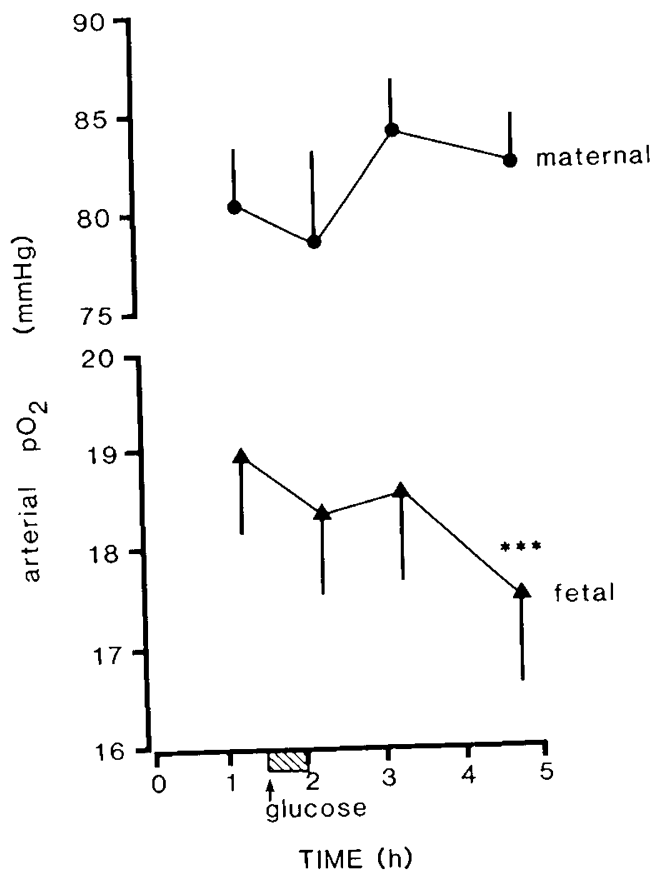

Fig. 3. Mean \pm SEM maternal (closed circles) and fetal (closed triangles) arterial $\mathrm{PO}_{2}$ prior to and following the infusion of $100 \mathrm{~g}$ glucose. There was a significant fall in fetal $\mathrm{PO}_{2}\left({ }^{* * *} p<0.001\right)$.

at the end of the experiment (Fig. 4). There was an increase in lung liquid osmolality following the infusion of glucose (Fig. 4; $p<0.02$ ). Osmolar excretion by the lungs remained constant (Fig. 4).

\section{DISCUSSION}

The infusion of $100 \mathrm{~g}$ glucose to the ewe caused maternal and fetal hyperglycemia which was sustained for the duration of the experiment. Fetal hyperglycemia was associated with a significant metabolic acidosis, i.e. there was a reduction in fetal arterial $\mathrm{pH}$ and bicarbonate levels and a rise in fetal $\mathrm{PCO}_{2}$ (Fig. 2). Although lactic acid levels were not measured in the present study, fetal hyperglycemia is known to cause lactacidemia $(4,8)$ which was probably responsible for the observed fall in bicarbonate levels and arterial $\mathrm{pH}$. There are two reasons why hyperglycemia may cause lactacidemia. First, about two-thirds of the glucose reaching the placenta is utilized and lactate produced (9). This lactate then enters the fetal circulation despite higher levels in fetal relative to maternal blood (10). Second, aerobic metabolism of excess amounts of glucose reaching the fetus will be limited by the amount of available oxygen. Thus lactate may also be generated in fetal tissues through anaerobic pathways. It therefore follows that the lower the fetal oxygen tension the greater the acidosis (4).

In the present study fetal hyperglycemia resulting directly from maternal hyperglycemia was associated with a small but significant decrease in fetal $\mathrm{PO}_{2}$ from a control level of $18.96 \pm 0.81$ $\mathrm{mm} \mathrm{Hg}(n=8$, see Fig. 3$)$. In other studies from this laboratory, mean values for $\mathrm{PO}_{2}$ range from 17 to $21 \mathrm{~mm} \mathrm{Hg}(11,12)$. A similar fall in arterial $\mathrm{PO}_{2}$ during chronic infusion of glucose to the fetus was described by Philipps et al. (13). They also showed an increase in fetal oxygen extraction which indicated an increase in oxygen consumption. Furthermore, the greater the hyperglycemia the greater the fall in arterial $\mathrm{PO}_{2}$.

Bassett and Madill (8) showed that fetal hyperglycemia stimulates the release of insulin from the fetal pancreatic B cells. Increased levels of insulin could cause a number changes; $c . g$. increased cellular uptake of circulating glucose, the conversion of glucose to liver glycogen, and the conversion of fatty acids to triglycerides for storage in adipose tissue, all of which increase oxygen consumption (14). In fact, the infusion of exogenous insulin into the fetus is associated with increased oxygen extraction which indicates an increase in oxygen consumption by the fetus (15).

The present findings show that fetal hyperglycemia resulting from maternal hyperglycemia is associated with both an acidosis and a fall in $\mathrm{PO}_{2}$. If the fetus was already "at risk" a fall in pH 

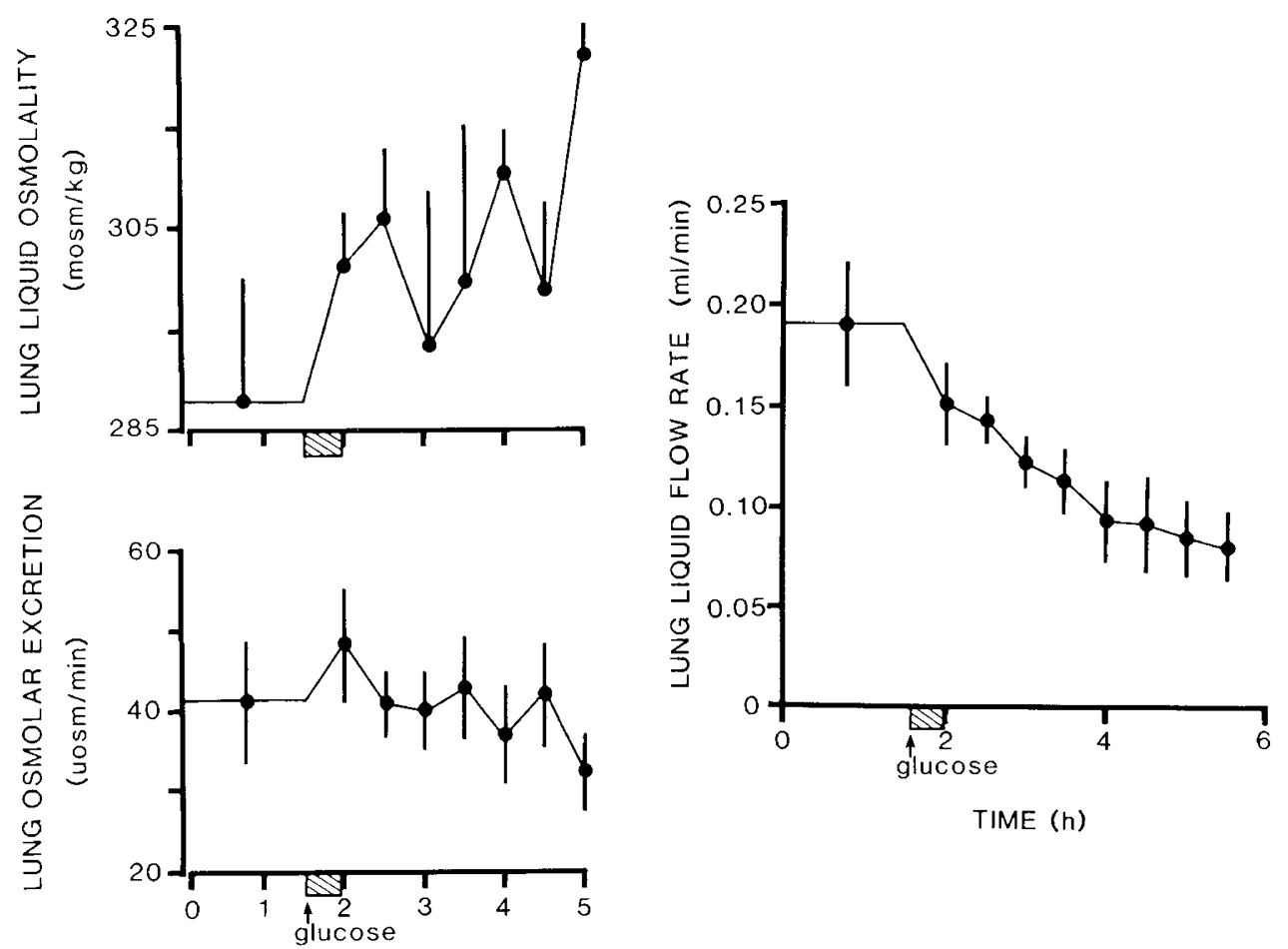

TIME (h)

Fig. 4. Mean $\pm \mathrm{SEM}$, lung liquid flow rate $(\mathrm{ml} / \mathrm{min}$, right) as well as lung liquid osmolality $(\mathrm{mosmol} / \mathrm{kg}$, left top) and osmolar excretion by the fetal lungs ( $\mu \mathrm{osmol} / \mathrm{min}$, left bottom) prior to and following the infusion of $100 \mathrm{~g}$ glucose to the ewe. There was a significant decrease in lung liquid flow rate $30 \mathrm{~min}$ after the infusion $(p<0.05)$ to a minimum at the end of the experiment $(p<0.001)$. Although there was a significant increase in the osmolality of lung liquid $(p<0.02)$ there was no change in lung osmolar excretion.

and $\mathrm{PO}_{2}$ induced by hyperglycemia might cause fetal death. In fact, in one experiment, fetal arterial $\mathrm{PO}_{2}$ fell to $11.3 \mathrm{~mm} \mathrm{Hg}$ within $2 \mathrm{~h}$ of the infusion of glucose and the fetus died a further $2 \mathrm{~h}$ later. It is difficult to extrapolate these findings to the diabetic pregnant woman. Levels of $750 \mathrm{mg} / \mathrm{dl}$, similar to those measured within $15 \mathrm{~min}$ of the infusion of glucose in the present study, will only occur in severe diabetes. However, these peak levels were not sustained and after $2.5 \mathrm{~h}$ the levels declined to those commonly seen in the diabetic woman.

In the present study the production of liquid by the fetal lungs decreased significantly following infusion of glucose to the ewe and when the fetus was hyperglycemic. The simplest explanation for this reduction in lung liquid production is the increase in fetal plasma osmolality resulting from fetal hyperglycemia. This increase in plasma osmolality would reduce the movement of water across the pulmonary epithelium. Such a conclusion is supported by the observation that lung liquid osmolality increased while osmolar excretion by the lungs did not change. However, it is possible that other mechanisms were responsible for the reduction in lung liquid production. It could be secondary to increased levels of endogenous $\mathrm{ADH}$ since lung liquid secretion is decreased following infusion of arginine vasopressin to the fetus $(16,17)$. However, hyperosmolality associated with hyperglycemia in the adult, is not a stimulus for ADH release due both to an increase in plasma glucose, a solute ineffective in stimulating $\mathrm{ADH}$ release, and a decrease in plasma sodium, an effective stimulator (18). This is probably also the case in this study since fetal plasma sodium levels fell with hyperglycemia (see Table 1).

The fall in lung liquid production may have been catecholamine-mediated due to the stimulatory effects of hypoxia on catecholamine release, since neither blood gas status nor lung liquid production were altered when fetal plasma glucose levels were chronically maintained at $32 \mathrm{mg} / \mathrm{dl}$ (19). Interestingly, Warburton (19) did find that the surface active phospholipid content of tracheal fluid was reduced compared with control fetuses. Alcorn et al. (20) showed that continuous drainage of fetal lung liquid was associated with a reduction in tissue growth and changes in differentiation of the pulmonary epithelium suggesting that a critical rate of lung liquid flow or a critical volume of fluid in the lungs seems to be necessary for normal maturation of the pulmonary epithelium and development of the type II cells responsible for the production of surfactant.

Acknowledgments. The authors acknowledge the excellent technical assistance of Miss V. J. Bennett and Mr. A. D. Stevens.

\section{REFERENCES}

1. Lemons JA, Vargas P, Delaney JJ 1981 Infant of the diabetic mother: review of 225 cases. Obstet Gynecol 57:187-192

2. White $P 1974$ Diabetes mellitus in pregnancy. Clin Perinatal 1:331-347

3. Gillmer DG, Beard RW, Brooke FM, Oakley NW 1975 Carbohydrate metabolism in pregnancy. Part 1. Diurnal plasma glucose profile in normal and diabetic women. Br Med J 3:399-402

4. Shelley HJ 1973 The use of chronically catheterised foetal lambs for the study of foetal metabolism. In: Comline KS, Cross KW, Dawes GS, Nathanielsz PW (eds) Foetal and Neonatal Physiology-The Sir Joseph Barcroft Centenary Symposium. Cambridge University Press, Cambridge, pp 360-381

5. Lumbers ER, Smith FG, Stevens AD 1985 Measurement of net transplacental fluid transfer to the fetal sheep. J Physiol 364:289-299

6. Keston AS 1956 Specific calorimetric enzymatic analytical reagents for glucose. Am Chem Soc (abstr 31C)

7. Armentrout T, Katz S, Thornburg KL, Faber JJ 1977 Osmotic flow through the placental barrier of chronically prepared sheep. Am J Physiol 233:H466$\mathrm{H} 474$

8. Bassett JM, Madill D 1974 Influence of prolonged glucose infusions on plasma insulin and growth hormone concentrations of foetal lambs. J Endocrinol 62:299-309

9. Battaglia FC 1984 The comparative physiology of fetal nutrition. Am J Obstet Gynecol 148:850-858

10. Sparks JW, Hay WW, Meschia G, Battaglia FC 1983 Partition of maternal nutrients to the placenta and fetus in the sheep. Eur J Obstet Gynecol Reprod Biol 14:331-340

11. Kesby GJ, Lumbers ER 1986 Factors affecting renal handling of sodium, hydrogen ions and bicarbonate by the fetus. Am J Physiol 251:F226-F231 
12. Lumbers FR, Stevens AD 1987 The effects of furosemide, saralasin and hypotension on fetal plasma renin activity and on fetal renal function. $J$ Physiol (in press)

13. Philipps AF. Porte PJ. Stabinsky S. Rosenkrantz. TS, Raye JR 1984 Effects of chronic fetal hyperglycaemia upon oxygen consumption in the ovine uterus \& conceptus. J (lin Invest 74:279-286

14. Goodman HM 1980 The pancreas and regulation of metabolism. In: Mountcastle VB (eds) Medical Physiology, Vol 2, 14th ed. C.V. Mosby Company. Si. Louis, MO, pp 165.3-1656

15. Milley JR, Rosenburg AA, Philipps AF, Molteni RA, Jones Jr MD. Simmons MA 1984 The effect of insulin on ovine fetal oxygen extraction. Am J Obstet Gynecol 149:673-678

16. Ross MG, Ervin (i. Leake RD, Fu P. Fisher DA 1984 Fetal lung liquid regulation by neuropeptides. Am J Obstet Gynecol 150:421-425

17. Perks AM. Cassin S 1985 The effects of arginine vasopressin on lung liquid secretion in chronic fetal sheep. In: Jones CT. Nathanielsz. PW (eds) The Physiological Development of the Fetus and Newhorn. Academic Press Inc London. pp 253-257

18. Robertson GL 1985 Regulation of vasopressin secretion. In: Seldin DW Giebisch $G$ (eds) The Kidney: Physiology and Pathophysiology. Raven Press. New York. pp 869-884

19. Warburton $D$ 1983 Chronic hyperglycemia reduces surface active material flux in tracheal fluid of fetal lambs. J Clin Invest 71:550-555

20. Alcorn D Adamson TM, Lambert TF Maloncy JE, Ritchic BC Robinson PM 1977 Morphological effects of chronic tracheal ligation and drainage in the fetal lamb lung. J Anat 123:649-660 